\title{
PENGEMBANGAN PERANGKAT PEMBELAJARAN TEAM BASED LEARNING DALAM PEMBELAJARAN DARING UNTUK MENINGKATKAN HASIL BELAJAR SISWA
}

\author{
Suryani M Laune'), Asri Arbie ${ }^{1)}$, Abd Wahidin Nuayi"1) \\ 1)Pendidikan Fisika, FMIPA, Universitas Negeri Gorontalo, Kota Gorontalo, Provinsi Gorontalo, Indonesia) \\ Corresponding author : Suryani M Laune \\ E-mail :yanilaune4578@gmail.com
}

Diterima 11 Oktober 2021, Direvisi 01 November 2021, Disetujui 01 November 2021

\begin{abstract}
ABSTRAK
Penelitian ini dilakukan disekolah SMA Negeri 4 Gorontalo dan bertujuan untuk menghasilkan perangkat pembelajaran yang berkualitas dengan menggunakan model Team Based Learning pada proses pembelajaran daring. Perangkat pembelajaran dikembangkan menggunakan model pengembangan ADDIE. Hasil penelitian terhadap perangkat menunjukan bahwa perangkat tersersebut berkualitas. Perangkat pembelajaran ini valid untuk digunakan dengan sedikit revisi Hal ini dapat dilihat berdarkan rata-rata hasil validasi dengan nilai 3,0-3,4. Efektivitas perangkat pembelajaran dapat dilihat dengan peningkatan hasil belajar siswa yang terdiri dari ranah kognitif pada pertemuan satu sampai pertemuan ketiga diperoleh N Gain iRat 0,66, 0,59, 0,51 dengan kriteria N Gain Sedang, pada tRat diperoleh N Gain $0,7,0,66$, dan 0,61 untuk ranah sikap dengan rata-rata persentase sebesar $80,44 \%$, serta ratarata persentase ranah keterampilan sebesar $80,17 \%$, dan hasil pengamatan aktivitas peserta didik selama tiga kali pertemuan yaitu sebesar $81,85 \%$ dengan kriteria sangat baik. Perangkat pembelajaran dikatakan praktis dilihat berdasarkan rata-rata hasil persentase keterlaksanaan selama tiga kali pertemuan yaitu sebesar $95 \%$, serta hasil angket respon guru dan peserta didik terkait perangkat pembelajaran pada proses pembelajaran daring mendapatkan respon positif.
\end{abstract}

Kata kunci: hasil belajar; perangkat pembelajaran; team based learning.

\begin{abstract}
This research was conducted at Gorontalo State High School 4 and aims to produce quality learning tools using the Team Based Learning model in the online learning process. Learning tools are developed using the ADDIE development model. The results of research on the device showed that the device was of quality. Learning devices are said to be valid for use with a slight revision this can be seen based on the average validation result with a value of 3.0-3.4. The effectiveness of learning devices can be seen by the improvement of student learning outcomes consisting of cognitive realms at meetings one to the third meeting obtained N Gain iRat $0.66,0.59,0.51$ with the criteria N Medium Gain, on tRat obtained N Gain $0.7,0.66$, and 0.61 for the realm of attitude with an average percentage of $80.44 \%$, as well as an average skill realm percentage of $80.17 \%$, and the results of observation of student activities during three meetings, namely $81.85 \%$ with excellent criteria. The learning device is said to be practically seen based on the average results of the percentage of implementation during three meetings, which is $95 \%$, as well as the results of teacher and student response questionnaires related to learning devices in the online learning process get a positive response.
\end{abstract}

Keywords: learning outcomes; learning devices; team based learning.

\section{PENDAHULUAN}

Tahun 2020 dunia digemparkan dengan adanya virus terbaru yang biasa di sebut dengan covid-19, virus ini memiliki karakteristik yaitu ukurannya yang sangat kecil dan dapat menyebar dengan sangat cepat. akibat dari penyebarannya yang sangat cepat membuat semua negara yang ada di dunia termaksud indonesia mengalami krisis kesehatan. Awalnya penyebaran Covid-19 ini sangat berdampak pada kegiatan ekonomi dimana ekonimi sekarang mulai lemah. Sebagai upaya untuk mencegah penyebaran Covid-19 pemerintah dibeberapa daerah juga membuat kebijakan penutupan jalan hingga pembatasan wilayah (Handarini dan Wulandari 2020 :496). Perserikatan bangsa-bangsa atau PBB menyatakan bahwa salah satu sektor yang terdampak adanya Covid-19 ini adalah dunia pendidikan (Purwanto et al. 2020). Pada kondisi seperti ini semua guru atau tenaga pendidik diharuskan untuk mengganti pembelajaran 
yang biasanya dilakukan dengan tatap muka sekarang dilakukan secara daring.

Pembelajaran secara daring adalah salah satu upaya pemerinta untuk memutus penyebaran Covid-19 serta menjaga kesehatan dan keselamatan guru dan peserta didik. Sesuai dengan adanya Surat Edaran Kementrian Pendidikan dan Kebudayaan (Kemendikbud) Direktorat Pendidikan Tinggi No. 1 Tahun 2020 mengenai pencegahan penyebaran Covid-19 di dunia pendidikan dalam surat edaran tersebut Kemendibud menginstruksikan untuk menyelenggarakan pembelajaran jarak jauh dan menyarankan para peserta didik untuk belajar dari rumah masingmasing. Pembelajaran daring selain sebagai usaha untuk memutus penyebaran Covid-19 adalah sebuah alternatif yang dilakukan pemerinta agar proses belajar mengajar tetap dilaksanakan pada masa pandemic Covid-19.

Perangkat Pembelajaran adalah sekumpulan pedoman belajar yang memungkinkan guru dan siswa melakukan pembelajaran. Menurut Usman Mustaming, Mochamad \& Luthfiyah (2015:5) menyatakan bahwa perangkat pembelajaran merupakan prasyarat bagi terjadinya interaksi belajar mengajar yang optimal. Merujuk pada pernyataan tersebut perangkat pembelajaran yang dipersiapkan mempengaruhi proses pembelajaran dikelas yang merupakan perangkat yang harus disiapkan seorang guru dalam megelola pembelajaran. Menurut ibrahim (Trianto 2008 :121) perangkat pembelajaran yang diperlukan dalam mengelola proses belajar mengajar dapar berupa: silabus, rencana pelaksanaan pembelajaran (RPP), lembar kegiatan peserta didik (LKPD), instrumen evaluasi, atau tes hasil belajar (THB), media pembelajaran serta buku ajar siswa.

Team Based Learning (TBL) merupakan salah satu pembelajaran yang mendorong siswa secara berkelompok atau saling berinteraksi sosial untuk aktif memecahkan masalah yang diberikan. Sesuai dengan teori Vygotsky yang mengatakan bahawa dengan bekerja secara kelompok akan mamapu memacu pengkonstruksian ide-ide baru dan mengembangkan intelektualitas siswa. Seperti yang dikatakan Michaelsen, (2014) bahawa pembelajaran secara berkolompok akan memaksa siswa berperan lebih aktif lagi dalam menerapkan konsep pelajaran yang dipelajari pada saat berinteraksi dengan teman anggota kelompok lainya. Pada pembelajaran Team Based Learning terdapat tiga tahapan pembelajaran yakni Preparation, Readiness Assurance, dan Application Of course Concept. Tahapan dapat di lihat pada Gambar 1.

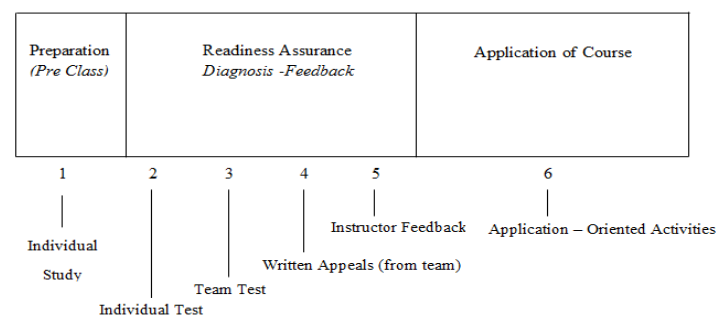

Gambar 1. Tahapan dalam pembelajaran Team Based Learning Menurut Michaelsen (Sumber:https:images.app.goo.gl/JxjKaewUefq dpAjEA)

Menurut Michaelsen \& Sweet (2008:8-9) tujuan utama dalam TBL yaitu untuk membuat peserta didik tidak hanya sekedar fokus pada konseptual namun peserta didik juga memiliki kesempatan untuk berlatih menggunakan konsep untuk menyelesaikan permasalahan. Pada pembelajaran Team Based Learning yang membuat peserta didik tidak hanya berfokus pada pemahaman konsep namun juga dari konsep itulah dapat dimanfaatkan dalam memecahkan permasalahan yang ada, perubahan itu tentunya tidak hanya terjadi secara otomatis dengan mudahnya. Untuk itu terdapat empat elemen penting yang perlu diperhatikan agar Team Based Learning dapat berhasil diterapkan, yaitu:

1. Grup; grup harus dibentuk, dan grup yang dibentuk harus dikelolah dengan baik

2. Akuntabilitas; peserta didik harus bertanggung jawab terhadap kualitas kerja diri dan kelompok mereka.

3. Umpan balik; peserta didik harus menerima umpan balik yang sering dan tepat pada waktunya sehingga membuat peserta didik menjadi semakin bertanggung jawab.

4. Desain penugasan; tugas kelompok harus mendorong pembelajaran dari pengembangan tim.

Menurut Lohman \& Finkelstein, (2002:1) satu hal yang membedakan pembelajaran berbasis tim dengan pembelajaran yang lainnya yaitu pembelajaran berbasis tim menempatkan penekanan kuat pada ikatan erat dan fungsi tim. Pembelajaran berbasis tim membedakan kelompok belaka dari sebuah tim dengan mencirikan kelompok sebagai kumpulan orang, sedangkan tim sejati ditentukan oleh tingkat komitmen, keintiman dan kepercayaan yang tinggi serta integrasi anggota kedalam peran yang saling mendukung atas kepentingan yang saling menguntungkan.

Menurut Kristina, Sari, dan Nagara (2002:3) pembelajaran daring merupakan kegiatan pembelajaran yang dilakukan dengan cara memanfaatkan perangkat-perangkat digital dan internet untuk menjadikan pembelajaran lebih menarik, kreatif dan 
mandiri. Pembelajaran daring meliputi penyampaian materi dan informasi, pemberian tugas dan interaksi aktif antara guru dan siswa selama proses pembelajaran berlangsung. Proses pembelajaran daring masih banyak memiliki kendala dalam proses pembelajarannya sperti sering kali didapati peserta didik kurang aktif dalam proses pembelajaran, kurangnya pemahaman peserta didik terhadap materi yang disampaikan guru dikarenakan proses pembelajarannya hanya dalam bentuk pemberian tugas, peserta didik kurang bisa menyampaikan aspirasi dan pendapatnya, sehingga pada akhirnya pembelajaran daring dirasakan tidak lebih menyenangkan dibandingkan dengan pembelajaran tatap muka. Permasalahan lain yang juga sering terjadi khususnya pada mata pelajaran fisika yaitu kurang efektifnya pelaksanaan praktikum selama diberlakukannya pembelajaran online. Hal ini disebabkan karena pelaksanaan praktikum biasanya hanya dilakukan di sekolah.

Mengacu pada permasalahan tersebut pembelajaran daring pada saat ini memerlukan inovasi agar pembelajaran lebih berkualitas. Salah satu solusi yang dapat dilakukan oleh guru yaitu berinovasi dengan mengembangkan perangkat pembelajaran yang menggunakan model, metode, dan pendekatan yang sesuai dengan kondisi saat ini.

Salah satu model yang dapat dijadikan sebagai inovasi untuk mengatasi masalah di atas adalah model pembelajaran Team Based Learning. Model ini dipilih karena dapat menjadi tantangan bagi siswa untuk berpartisipasi langsung dalam mengkonstruksi konsep. Seperti yang dikemukakan oleh Menurut Michaelsen, Davidson, dan Major (2014:58) keefektifan Team Based Learning dapat dilihat melalui dua hal yaitu: (1) TBL mengalihkan fokus pengajaran dari guru sebagai penyebar informasi dan sebaliknya menempatkan fokus pada siswa yang secara aktif terlibat dalam kegiatan yang mengharuskan mereka menggunakan konsep untuk memecahkan masalah, dan (2) setiap aspek dari TBL dirancang khusus untuk membantu perancangan kelola tim belajar. Dengan demikian dikelas siswa terlibat aktif satu sama lain dalam upaya menerapkan konsep untuk memecahkan masalah otentik.

Blount (Islamarida 2019:13). Team Based Learning menawarkan alternatif pada pembelajaran tradisional dan menimbulkan inovasi baru guna memfasilitasi siswa dalam berpikir kritis dan kerja sama. Sejalan dengan hal ini menurut Persky (2012:2) pembelajaran berbasis tim dapat meningkatkan profesionalisme siswa dan memberikan kesempatan untuk mengembangkan keterampilan yang diperlukan dalam dunia kerja. Guna mengoptimalkan proses pembelajaran daring adapun tujuan dari penelitian ini yaitu mengembangkan perangkat pembelajaran Team based Learning dalam pembelajaran daring untuk meningkatkan hasil belajar siswa.

\section{METODE}

Penelitian ini merupakan penelitian dan pengembangan (Research and Development) dengan menggunakan model pengembangan ADDIE. Teknik pengumpulan data dari penelitian ini yaitu melalui uji validitas konstruk dan kepraktisan melalui observasi keterlaksanaan pembelajaran, angket respon guru dan peserta didik terhadap proses pembelajaran menggunakan perangkat pembelajaran Team Based Learning. Teknik analisis data yang digunakan yaitu analisis deskriptif terhadap hasil validasi perangkat pembelajaran, observasi keterlaksanaan dianalisis dengan menghitung persentase keterlaksanaan, dan angket respon guru dan respon peserta didik dianalisis menggunakan Skala Likert. Adapun alur rancangan pada penelitian ini sebagai berikut.

\section{HASIL DAN PEMBAHASAN Hasil Penelitian}

Langkah-langkah yang dilakukan pada tahap pengembangan perangkat pembelajaran dengan menggunakan model Team Based Learning adalah sebagai berikut;

Tahap Analysis, pada tahap ini peneliti melakukan dua analisis yaitu analisis kinerja dan analisis kebutuhan. Pada analisis kinerja peneliti melakukan observasi untuk mengetahui masalah awal disekolah mengenai proses pembelajaran Sebagai dasar untuk mengembangakan perangkat pembelajaran. Setelah itu kemudian peneliti melakukan analisis kebutuhan dimana peneliti memberikan solusi terhadap permasalahan yang terdapat di SMA Negeri 4 Gorontalo. Berupa pengembangan perangkat pembelajaran yang meliputi Silabus, RPP, Bahan Ajar, LKPD, Instrumen penilaian hasil belajar.

Tahap Design pada tahap ini yang dilakukan peneliti adalah membuat kerangka/spesifikasi secara rinci mengenai kebutuhan materi untuk produk. Produk dalam hal ini yaitu perangkat pembelajaran yang dikembangkan menggunakan model Team Base leraning. Dalam tahap perancangan ini, terdapat beberapa rancangan perangkat pembelajaran yaitu berupa rancangan silabus, RPP, Bahan Ajar, LKPD, THB, serta Instrumeninstrumen penilaian. 
Tahap selanjutnya yaitu tahap Development pada tahap ini yang dilakukan peneliti yaitu melakukan beberapa perbaikan terhadap perangkat pembelajaran yang telah divalidasi oleh tiga validator sesuai dengan komentar dan saran yang diberikan validator. Setelah dilakukan perbaikan perangkat pembelajaran, telah menghasilkan perangkat pembelajaran yang valid maka langkah yang dilakukan selanjutnya yaitu tahap implementasi.

Tahap Implementation yang dilakukan peneliti adalah melalukan proses pembelajaran menggunakan perangkat pembelajaran telah dikembangkan oleh peneliti yang telah selesai divalidasi oleh tiga validator. Dan tahap terakhir dari model pengembangan yang dilakukan adalah tahap Evaluation pada tahap evaluasi yang dilakukan peneliti adalah mengevaluasi seluruh proses pengembangan perangkat pembelajaran, baik dari segi kesesuaian perangkat pembelajaran maupun penerapannya dalam kelas. Peneliti melakukan evaluasi dengan cara memberikan angket respon guru tentang perangkat pembelajaran yang dikembangkan, dan memberikan angket respon peserta didik mengenai model pembelajaran yang dilakukan dalam kelas.

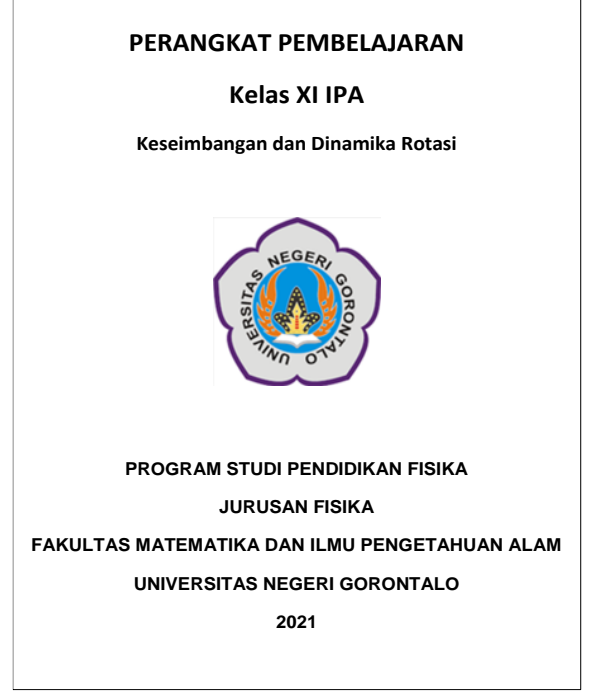

Gambar 2. Perangkat Pembelajaran

\section{Validitas Perangkat Pembelajaran}

Validasi dilakukan oleh 3 orang validator yang berkompetensi memberikan penilaian masukkan dan saran untuk menyempurnakan draf perangkat pembelajaran yang telah dibuat.validasi perangkat mencakup keterbacaan, kelayakan isi, keterbacaan dan tampilan. Hasil dari penilaian, koreksi, masukan dan saran validator dijadikan dasar untuk merevisi desain perangkat pembelajaran yang telah dibuat sehingga dihasilkan perangkat final.

Tabel 1. Hasil Validasi Perangkat

$$
\text { Pembelajaran }
$$

Instrumen Nilai rata-rata Validasi

\begin{tabular}{cc}
\hline Silabus & 3,4 \\
\hline RPP & 3,14 \\
\hline Bahan Ajar & 3 \\
\hline THB & 3,48 \\
\hline Angket & 3,25 \\
\hline LKPD & 3,04 \\
\hline
\end{tabular}

Berdasarkan tabel 1. dapat dilihat bahwa rata-rata hasil validasi dari ketiga validator 3,0 dan 3,4 sehingga diperoleh perangkat pembelajaran yang dikembangkan valid dan layak untuk diuji coba.

\section{Kepraktisan Perangkat Pembelajaran}

Kepraktisan perangkat pembelajaran Team Based Learning diukur melalui observasi keterlaksanan pembelajaran, kuesioner (angket) respon guru terhadap perangkat pembelajaran Team Based Learning, dan kuesioner (angket) peserta didik mengenai proses pembelajaran menggunakan perangkat pembelajaran Team Based Learning. Adapun hasil penelitian untuk kepraktisan perangkat pembelajaran diperoleh sebagai berikut.

\section{a. Keterlaksanaan pembelajaran}

Data keterlaksanaan pembelajaran diperoleh melalui lembar observasi keterlaksanaan yang diisi oleh pengamat pada saat peneliti melakukan proses pembelajaran di sekolah. Lembar observasi keterlaksanaan berisi langkah-langkah pembelajaran pada RPP dengan melihat terlaksananya atau tidak langkah-langkah pembelajaran yang ada pada RPP. Adapun hasil pengamatan observasi keterlaksanaan pembelajaran diperoleh sebagai berikut.

Tabel 2. PersentaseKeterlaksanaan

\begin{tabular}{|c|c|c|}
\hline $\begin{array}{l}\text { Pengamat } \\
\text { pertemuan }\end{array}$ & $\begin{array}{c}\text { Keterlaksanaan Pembelajaran } \\
(\%)\end{array}$ & Kriteria \\
\hline 1 & 100 & Sangat Baik \\
\hline 2 & 95 & Sangat Baik \\
\hline 3 & 90 & Sangat Baik \\
\hline Rata-rata & 95 & Sangat Baik \\
\hline
\end{tabular}

Berdasarkan tabel 2. Dapat dilihat bahwa skor rata-rata keterlaksanaan pembelajaran yakni sebesar $95 \%$ dan termasuk dalam kategori sangat baik.

\section{b. Angket Respon Guru}

Angket respon guru dalam penelitian ini digunakan untuk mengetahui respon guru terhadap perangkat pembelajaran yang dikembangkan dengan menggunakan model Team Based Learning. Adapun hasil kuesioner (angket) respon guru sebagai berikut.

Tabel 3. Persentase respon guru 


\begin{tabular}{ccccc}
\hline Indikator & Skor & $\begin{array}{c}\text { Skor } \\
\text { Maksimal }\end{array}$ & $\%$ & Kriteria \\
\hline Silabus & 48 & 60 & 80 & Baik \\
RPP & 144 & 180 & 80 & Baik \\
Bahan Ajar & 72 & 90 & 80 & Baik \\
THB & 36 & 45 & 80 & Baik \\
LKPD & 20 & 25 & 80 & Baik \\
$\begin{array}{c}\text { Peer dan self } \\
\text { Penggunaan }\end{array}$ & 24 & 30 & 80 & Baik \\
model & 20 & 25 & 80 & Baik \\
Kualitas & 12 & 15 & 80 & Baik \\
pengembangan & Rata-rata & & $\mathbf{8 0 . 0 0}$ & Baik \\
\hline
\end{tabular}

Berdasarkan tabel 3. dapat dilihat bahwa skor rata-rata hasil angket respon guru untukb. keseluruhan indikator sebesar $80 \%$ danc. termasuk dalam kategori baik.

\section{c. Angket Respon Peserta Didik}

Angket respon peserta didik digunakan guna melihat tanggapan peserta didik mengenai proses pembelajaran dengan menggunakan perangkat pembelajaran Team Based Learning. Adapun hasil angket respon peserta didik sebagai berikut.

Tabel 4. Persentase respon peserta didik

\begin{tabular}{lcc}
\hline \multicolumn{1}{c}{ Indikator } & $\begin{array}{c}\text { Persentase Respon } \\
\text { Peserta Didik (\%) }\end{array}$ & Kriteria \\
\hline $\begin{array}{l}\text { Tanggapan siswa terhadap } \\
\text { pembelajaran tim }\end{array}$ & 81,92 & Baik \\
\hline Kesan siswa pada pembelajaran tim & 80,8 & Baik \\
\hline $\begin{array}{l}\text { Perasaan siswa selama } \\
\text { pembelajaran }\end{array}$ & 80,53 & Baik \\
$\begin{array}{l}\text { Ketertarikan siswa pada } \\
\text { pembelajaran tim }\end{array}$ & 82 & Baik \\
$\begin{array}{l}\text { Perhatian peserta didik pada saat } \\
\text { pembelajaran }\end{array}$ & 80 & Baik \\
\hline $\begin{array}{l}\text { Hasil belajar siswa setelah } \\
\text { pembelajaran tim }\end{array}$ & 82,53 & Baik \\
\hline \begin{tabular}{l} 
Efektivitas penggunaan LKPD \\
\multicolumn{1}{c}{ Rata-rata }
\end{tabular} & 82.72 & Baik \\
\hline & 81,50 & Baik \\
\hline
\end{tabular}

Berdasarkan tabel 4. dapat dilihat bahwa hasil angket respon peserta didik untuk keseluruhan indikator yaitu sebesar $81,50 \%$ dan termasuk dalam kategori baik.

\section{Kefektifian Perangkat Pembelajaran}

Kefektifan perangkat pembelajaran pada penelitian ini didasarkan dengan beberapa indikator, yaitu: aktivitas peserta didik dan tes hasil belajar yang terdiri dari ranah kognitif, afektif dan psikomotor. Berdasarkan observasi dan tes yang telah dilakukan peneliti didapatkan hasil sebagai berikut:

\section{a. Aktivitas peserta didik}

Penialian aktivitas peserta didik dilakukan dengan mengisi aktivitas yang dilakukan oleh peserta didik pada lembar aktivitas peserta didik. Penilaian dilakukan selama 3 kali pertemuan pada saat pembelajaran dengan melihat nomor peserta didik untuk memudahkan pengamat dalam memberikan penilaian. Lembar aktivitas yang dimaksud adalah lembar aktivitas peserta didik yang diobservasi selama proses pembelajaran berlangsung dengan hasil analisis data aktivitas peserta didik. Berdasarkan hasil pengamatan dan telah dianalisis didapatkan persentase aktivitas peserta didik sebagai berikut:

Tabel 5. Persentase Aktivitas Peserta Didik

\begin{tabular}{ccc}
\hline Pertemuan & $\begin{array}{c}\text { Persentase (\%) Aktivitas } \\
\text { Peserta Didik }\end{array}$ & Kriteria \\
\hline 1 & 82,51 & Sangat aktif \\
2 & 77,77 & aktif \\
3 & 83,85 & Sangat aktif \\
Rata-rata & 81,38 & Sangat aktif \\
\hline
\end{tabular}

Berdasarkan tabel 5. Dapat dilihat bahwa skor rata-rata hasil aktivitas peserta didik selama 3 kali pertemuan yaitu sebesar $81,38 \%$ dan termasuk dalam kategori sangat aktif.

\section{Tes Hasil Belajar Ranah kognitif}

Hasil belajar untuk ranah kognitif dilihat dari lembar tes hasil belajar (THB) Pretes dan posttes baik secara individu dan kelompok. Tes tersebut disusun berdasarkan indikator soal yang terdiri dari 15 butir soal essay sebanyak 3 kali pertemuan. Berdasarkan hasil tes yang dilakukan maka diperoleh keseluruhan nilai rata-rata pretes dan posttes baik secara individu maupun kelompok sebagaimana terdapat pada Tabel berikut:

Tabel 6. N Gain Hasil Belajar iRAT dan tRAT

$$
\text { IRAT }
$$

\begin{tabular}{|c|c|c|c|c|c|}
\hline Pertemuan & $\begin{array}{c}\text { Pree test } \\
(\%)\end{array}$ & $\begin{array}{c}\text { Post test } \\
(\%)\end{array}$ & Selisih & N Gain & Kriteria \\
\hline 1 & 40,79 & 80,22 & 39,43 & 0,66 & Sedang \\
\hline 2 & 49,43 & 79,13 & 29,7 & 0,59 & Sedang \\
\hline 3 & 54,96 & 78,05 & 23,09 & 0,51 & Sedang \\
\hline \multicolumn{6}{|c|}{ tRAT } \\
\hline Pertemuan & $\begin{array}{l}\text { Pree test } \\
\text { (\%) }\end{array}$ & $\begin{array}{l}\text { Post test } \\
(\%)\end{array}$ & Selisih & N Gain & Kriteria \\
\hline 1 & 56,7 & 87,06 & 30,36 & 0,7 & Sedang \\
\hline 2 & 55,66 & 85,03 & 29,37 & 0,66 & Sedang \\
\hline 3 & 66,04 & 86,74 & 20,7 & 0,61 & Sedang \\
\hline
\end{tabular}

berdasarkan tabel 6. Dapat dilihat bahwa hasil pelajar peserta didik pada ranah kognitif mengalami peningkatan di mana nilai pada melakukan tRAT lebih tinggi dibandingkan dengan nilaia pada saat melakukan iRAT.

\section{Ranah Afektif}

Hasil belajar untuk ranah afektif pada penelitian ini didasarkan pada lembar obsevasi sikap dan penilaian self dan peer asessment selama proses pembelajaran. Lembar observasi diamati oleh pengamat selama 3 pertemuan dan lembar self dan peer asessment dinilai oleh peserta didik. Persentase 3 pertemuan tersebut didapatkan nilai persentase rata-rata sebagai berikut:

Tabel 7. Persentase Sikap Peserta Didik

\begin{tabular}{ccc}
\hline Pertemuan & $\begin{array}{c}\text { Persentase (\%) Sikap Peserta } \\
\text { Didik }\end{array}$ & Kriteria \\
\hline 1 & 81,33 & Tinggi \\
2 & 77,33 & Tinggi \\
3 & 82,66 & Tinggi \\
Rata-rata & 80,44 & Tinggi \\
\hline
\end{tabular}

Tabel 8. Persentase self asessment 


\begin{tabular}{ccc}
\hline Pertemuan & $\begin{array}{c}\text { Persentase (\%) Sikap Peserta } \\
\text { Didik }\end{array}$ & Kriteria \\
\hline 1 & 81,1 & Sangat baik \\
2 & 77,74 & Baik \\
3 & 82,44 & Sangat baik \\
Rata-rata & 80,09 & Sangat baik \\
\hline
\end{tabular}

Tabel 9. Persentase Peer Asessment

\begin{tabular}{ccc}
\hline Pertemuan & $\begin{array}{c}\text { Persentase }(\%) \text { Sikap Peserta } \\
\text { Didik }\end{array}$ & Kriteria \\
\hline 1 & 79,06 & Baik \\
2 & 75,58 & Baik \\
3 & 82,68 & Sangat baik \\
Rata-rata & 79,10 & Baik \\
\hline
\end{tabular}

Berdasarkan tabel diatas dapat dilihat bahwa rata-rata hasil belajar peserta didik pada lembar observasi sikap sebesar $80,44 \%$ berada pada kategori tinggi. Untuk $\mathrm{n}$ nilai rata-rata self asessment sebesar $80,09 \%$ berada pada kategori sangat baik. Dan untuk nilai rata-rata peer asessment sebesar 79,10 berada pada kategori baik.

\section{Ranah Psikomotor}

Hasil belajar pada ranah psikomotor pada penelitian ini didasarkan pada lembar observasi keterampilan peserta didik selama proses pembelajaran, lembar observasi diamati oleh pengamat selama 3 pertemuan. Persentase 3 pertemuan tersebut didapatkan nilai persentase rata-rata sebagai berikut:

Tabel 10. Persentase Keterampilan Peserta

\begin{tabular}{ccc}
\multicolumn{3}{c}{ Didik } \\
\hline \multirow{2}{*}{ Pertemuan } & $\begin{array}{c}\text { Persentase }(\%) \text { Sikap Peserta } \\
\text { Didik }\end{array}$ & Kriteria \\
\hline 1 & 80,26 & Tinggi \\
2 & 77,86 & Tinggi \\
3 & 82,4 & Tinggi \\
Rata-rata & 80,17 & Tinggi \\
\hline
\end{tabular}

Berdasarkan Tabel 10. Dapat dilihat bahwa rata-rata hasil persentase keterampilan peserta didik delam 3 kali pertemuan sebesar $80,17 \%$ berada pada kategori tinggi.

\section{Pembahasan}

\section{Proses Pengembangan Perangkat Pembelajran}

Penelitian ini bertujuan untuk menghasilkan perangkat pembelajaran yang berkualitas untuk digunakan. Perangkat pembelajaran yang dihasilkan terdiri dari silabus, RPP, bahan ajar, LKPD dan instrumen penilaian hasil belajar yang terdiri dari penilaian sikap, penilian kognitif, dan penialian keterampilan. Penelitian ini juga memfokuskan pada kualitas perangkat untuk kegitan belajar mengajar. Untuk memenuhi tujuan tersebut, peneliti menggunakan model pengembangan ADDIE yang terdiri dari 5 tahap yaitu: Analysis, design, Development, Implementation, dan Evaluation.

Pada tahap analisis, peneliti melakukan analisis kinerja dan analisis kebutuhan di SMA
Negeri 4 Gorontalo, dan diperoleh berdasarkan hasil observasi langsung dan dianalisis bahwa yang menjadi salah satu permasalahan di sekolah tersebut adalah pada saat proses pembelajaran secara daring yang dilakukan yaitu hanya pemberian materi dan tugas tanpa melibatkan siswa untuk melakukan praktek terhadap materi yang diajarkan sehingga peserta didik kurang memahami materi yang diajarkan. Setelah melakukan analisis kebutuhan disekolah tersebut peneliti memutuskan untuk melakukan pengembangan perangkat pembelajaran mengunakan model Team Based Learning untuk meningkatkan hasil hasil belajar siswa.

Selanjutnya pada tahap design, peneliti merancang perangkat pembelajaran yang terdiri dari silabus, RPP, bahan ajar, LKPD, THB, self assessment dan peer assessment dengan menggunakan model Team Based Learning. Pada tahap selanjutnya yaitu tahap development dilakukan beberapa perbaikan terhadap perangkat pembelajaran yang dirancang sebelumnya yaitu melalui validasi yang dilakukan oleh validator yang berjumlah 3 orang, setelah melakukan revisi perangkat pembelajaran berdasarkan masukan dari validator maka dihasilkan perangkat yang valid dan siap untuk digunakan.

Setelah memperoleh perangkat pembelajaran yang valid, langkah selanjutnya yaitu implementation, Di SMA 4 Gorontalo proses pembelajaran di kelas XI IPA 1 dengan menggunakan perangkat yang telah dikembangkan, terlihat antusias peserta didik dalam mengikuti pembelajaran. Hal ini dikarenakan peserta didik tidak hanya berperan pasif dalam proses pembelajaran daring yakni hanya mendengarkan penjelasan guru tetapi dengan menggunakan perangkat pembelajaran yang telah dikembangan menggunakan model pembelajaran yang berbasis tim dapat membuat siswa lebih mandiri untuk mengetahui dan memahami materi yang akan di pelajari dengan memeberikan kesempatan keapda siswa untuk membaca dan mempelajari materi secara mandiri, kemudian memberikan kesempatan untuk siswa secara tim atau kelompok lebih aktif untuk memecahkan masalah tentang materi yang belum dipahami untuk menemukan solusi dari permasalahan tersebut.

Pada tahap terakhir yaitu Evaluation, dilakukan dengan cara mengevaluasi seluruh proses pengembangan perangkat pembelajaran. Baik dari segi kesesuaian perangkat pembelajaran maupun penerapannya dalam kelas. Peneliti melakukan evaluasi dengan cara memberikan angket respon guru tentang perangkat pembelajaran 
yang dikembangkan, dan memberikan angket respon peserta didik mengenai model pembelajaran yang dilaukan dalam kelas.

\section{Kualitas Perangkat Pembelajaran}

Kualitas perangkat pembelajan dilihat dari 3 kriteria yaitu valid, praktis, dan efektif. Kevalidan perangkat pembelajaran yang di kembangkan ditentukan dari komentar validator pada lembar validasi. Selanjutnya kepraktisan perangkat pembelajaran yang dikembangkan dilihat melalui persentase keterlaksanaan pembelajaran serta hasil angket respon guru dan peserta didik. Kefektifan perangkat pembelajaran dapat diketahui melalui persentase aktivitas peserta didik dan hasil hasil belajar pada ranah kognitif, sikap, dan keterampilan.

\section{a. Validitas Perangkat Pembelajaran}

Valid tidaknya perangkat pembelajaran yang digunakan dikelas ditentukan dengan komentar dari 3 orang validator pada lembar validasi. Komponen perangkat pembelajaran yang divalidasi terdiri dari komponen silabus, komponen RPP, komponen LKPD, komponen Bahan Ajar, komponen tes Hasil Belajar, komponen Self assessment dan Peer assessment, dan komponen instrument penilaian sikap dan keterampilan, komponen keterlaksanaan pembelajaran dan aktifitas peserta didik, serta komponen angket respon guru dan peserta didik.

Pada komponen silabus kevalidan dilihat dengan 5 indikator yaitu kostruksi isi, keterbacaan, dan bahasa dan penampilan. Hasil validasi oleh validator menunjukan dari segi kostruksi silabus telah sesuai dengan kaidah kurikulum 2013. Pada segi isi telah sesuai dengan tingkat kesesuain materi pokok dengan kompetensi dasar, kegiatan pembelajan, penilaian, alokasi waktu, dan sumber belajar. Dari segi keterbacaan dan bahasa silabus memiliki memiliki kalimat yang mudah dipahami dan sesuai dengan kidah EYD. Berdasarkan kesimpulan validasi silabus oleh validator diperoleh bahwa silabus telah layak digunakan dengan sedikit revisi.

Komponen RPP yang divalidasi oleh validator terdiri dari 3 pertemuan dan ditinjau dari kostruksi, kesesuaian isi, keterbacaan, bahasa dan penampilan. Hasil validasi yang diperoleh RPP yang dikembangkan sesuai dengan indikator penialian yang ditentukan, hanya masi dilakukan sedikit revisi dan perjelas kembali pada tujuan pembelajaran dalam RPP. Jadi dapat disimpulkan bahwa RPP yang telah dikembankan layak digunakan setelah dilakukan revisi sesuai dengan saran dan komentar validator.
Pada komponen LKPD, terdapat beberapa indikator yang dinilai yaitu dari segi kostruksi, isi, keterbacaan, bahasa, dan penampilan. LKPD yang layak digunakan harus mampu memenuhi seluruh indikator penialian yang ada. Hasil validasi oleh 3 orang validator diperoleh LKPD yang dikembangkan sudah sesuai dengan indikator penilaian hanya saja terdapat sedikit perbaikan pada petunjuk dan langkahlangkah percobaan. Melalui komentar dan saran dari validator yang diperoleh dilakukan perbaikan yang sesuai dengn saran berdasarkan hasil valdasi LKPD layak digunakan setelah dilakukan sedikit revisi.

Selanjutnya pada komponen bahan ajar kriteria valid bahan ajar terbagi menjadi bebrapa aspek kostruksi, isi, bahasa, keterbacaan, dan penampilan. Komentar dan saran dari ke 3 validator yaitu dilakukan sedikit perbaikan gambar pada bahan ajar dan pembuatan bahan ajar semenarik mungkin. Setelah dilakukan perbaikan sesuai dengan saran validator, disimpulkan bahwa bahan ajar layak digunakan dengan sedikit revisi.

Kriteria penilaian tes hasil belajar pada ranah kognitif, afektif, dan psikomotor terdiri dari indikator konstruksi, isi, keterbacaan, dan bahasa komentar dari validator yaitu agar dilakukan revisi berupa tes sesuai dengan indiator dan mengacu pada taksonomi bloom. Setelah dilakukan perbaikan hasil valdasi penialian tes hasil belajar pada ranah kognitif, afektif, dan psikomotor komponentersebut layak digunakan dalam pembelajaran dengan sedikit revisi.

Komponen instrument penialian keterlaksanaan pembelajaran dan aktivitas peserta didik dilakukan oleh validator dengan hasil bahwa instrument penialian layak untuk digunakan dengan sedikit revisi. Hal ini yang sama juga diperoleh pada keakuratan penilaian instrument angket respon guru dan siswa. Instrument ini dinyatakan layak digunakan sebagai salah satu instrument pengambilan data respon guru dan peserta didik terhadap perangkat pembelajaran yang telah dikembangkan.

\section{b. Kepraktisan perangkat pembelajaran}

kepraktisan perangkat pembelajaran yang dikembangkan ditentukan melalui persentase keterlaksanaan pembelajaran serta respon guru dan peserta didik. Persentase keterlaksanaan pembelajaran dilihat dari beberapa persen langkah pembelajaran yang berhasil dilakukan didalam kelas yang diamatai oleh pengamat, sedangkan respon guru dan peserta didik diperoleh dari angket respon yang dikakukan terhadap salah satu guru di SMA Negeri 4 Gorontalo dan siswa kelas XI IPA 1. 
Hasil pengamatan keterlaksanaan pembelajaran menunjukan bahwa pertemuan 1 diperoleh persentase keterlaksanaan pembelajaran mencapai $100 \%$, pada pertemuan Kedua mencapai 95\%, sedangkan pertemuan ketiga persentase keterlaksanaan mencapai $90 \%$. Rata-rata persentase keterlaksanaan selama 3 pertemuan yakni 95\%. Jumlah keterlaksanaan pembelajaran ini sesuai dengan kriteria kepraktisan perangkat pembelajaran dalam jurnal Purnomo (2015) yaitu sangat baik. Hal ini menunjukan bahwa lamgkah-langkah yang ada dalam RPP yang telah dikembangkan praktis atau mudah untuk digunakan dan diimplementasikan dalam pembelajaran.

Kriteria praktis atau tidaknya perangkat pembelajaran yang dikembangkan yakni dengan melihat respon guru dan peserta didik yang dilakukan dengan cara pemberikan angket. Berdasarkan pemberian angket yang dilakukan kepada guru dengan memberikan pernyataan tentang kepraktisan perangkat pembelajaran secara keseluruhan mendapatkan respon positif. Guru memberikan respon positif terhadap perangkat pembelajaran, persentase untuk angket respon guru yaitu sebesar $80 \%$ karena dinilai perangkan pembelajan yang dikembangkan terdapat perbedaan dengan perangkat yang suda ada sebelumnnya. dinilai mampun menabah minat dan hasil belajar peserta didik dalam pembelajaran dengan menggunakan model Team Base Learning, guru memberikan apresiasi yang positif dengan menggunakan model pembelajaran tersebut peserta didik menjadi terlibat secara aktif dalam proses pembelajaran baik individu maupun kelompok. Secara keseluruhan perangkat pembelajran yang dinilai mudah untuk digunakan dan diharapkan bisa disesuaikan dengan materi lain sesuai dengan kebutuhan.

Respon yang sama juga diperoleh dari angket respon peserta didik dikelas XI IPA 1 tersebut. Peserta didik memberikan respon yang postif terhadap penggunaan model pembelajan Team Based Learning dalam proses pembelajaran daring dengan menggunakan aplikasi Whatsapp dan Google Meet. Dengan persentase anget respon peserta didik yaitu sebesar $80 \%$.Pembelajaran dinilai sangat menyenangkan karena Karen peserta didik tidak hanya dikirimkan materi dan tugas tetapi peserta didik diarahkan belajar secara mandiri dan secara tim atau kelompok untuk berdiskusi tentang materi yang belum dipahami dengan cara melibatkan peserta didik untuk melakukan percobaan dengan menggunakan alat sederhana yang terdapat di rumah masing- masing sehinga siswa mudah memahami materi yang sedang diberikan.

Berdasarkan persentase keterlaksanaan pembelajaran serta respon positif dari guru dan peserta didik yang telah diuraikan diatas, dapat diketahui bahwa perangkat pebelajaran yang dikembangkan dinyatakan telah memenuhi kriteria keprsaktisan dan dapat digunakan dalam proses pembelajaran.

\section{c. Efektivitas perangkat pembelajaran}

Keefektifan perangkat pembelajaran ditinjau dengan 2 indikator yaitu persentase aktivitas peserta didik selama pembelajaran berlangsung dan hasil tes belajar yang diperoleh peserta didi pada ranah kognitif, sikap, dan keterampilan.

Persentase aktivitas selama kegiatan pembelajaran pada pertemuan pertama menunjukan angka $82,51 \%$, untuk pertemuan kedua aktivitas siswa menjadi $77,77 \%$ dan untuk pertemuan ketiga persentase aktivitas peserta didik yaitu sebesar $83,85 \%$. sehingga rata-rata persentase untuk 3 pertemuan mencapai $81,38 \%$ dengan kategori "sangat aktif" berdasarkan kriteria menurut Pathoni (2014:23). Hal ini menunjukan bahwa perangkat pembelajaran menggunakan Team Based Leaning (TBL) yang dikembangkan tergolong efektif jika dilihat dari segi aktivitas peserta didik.

Penilaian selanjutnya dilakukan pada ranah sikap peserta didik pada saat proses pembelajaran fisika berlangsung. Berdasarkan hasil penilaian yang diperoleh, pada pertemuan pertama persentase penilaian sikap peserta didik yakni $81,33 \%$, pada pertemuan 2 yaitu sebesar $77,33 \%$, dan pada pertemuan 3 yaitu $82,44 \%$. sehingga persentase rat-rata penilaian sikap peserta didik menjadi $80,44 \%$ dengan kategori "Tinggi" berdasarkan kriteria menurut Fatmawati (2016:4) Selain menggunakan lembar penilaian sikap peneliti juga menggunakan lembar penialain self assesment dan peer assessment untuk melakukan penilaian sikap terhadap peserta didik dalam proses pembelajaran. Persentase rata-rata untuk penilaian sikap menggunakan lembar penialian self assessment sebayak 3 pertemuan yaitu $80,09 \%$ sedangkan nilai persentase 3 pertemuan untuk penialian peer assessment yaitu $79,10 \%$. sehing ini menunjukan bahwa perangkat pembelajaran menggunakan model Team Based Learning (TBL) yang dikembangkan sangat efektif.

Penilaian keterampilan peserta didik yang digunakan untuk mengukur persentase keterampilan peserta didik dalam mekasanakan eksperimen yang dinilai pada setiap pertemuan, pada pertemuan 1, persentas eketerampilan 
peserta didik adalah $80,26 \%$, selanjutnya pada pertemuan ke 2 mencapai $77,86 \%$, dan pertemuan ke 3 yaitu $82,4 \%$. sehingga rata-rata persentase keterampilan peserta didik adalah $80,17 \%$ dengan kategori "tinggi" berdasarkan kriteria menurut Fatmawati (2016:4) hal ini menunjukan pembelajaran menggunakan model Team Based Learning efektif untuk diimplementasikan kepada peserta didik.

Penialian yang terakhir adalah penialain kognitif atau pengetahuan yang berupa tes hasil belajar peserta didik, penilaian ranah kognitif dinilaia dari tes hasil belajar yang terdiri dari pemberian pre test sebelum diberi perlakuan dan posttest setelah pembelajaran berakhir. Penilaian kognitif peserta didik diperoleh bahwa tes hasil belajar setelah perlakuan mencapai KKM 75 yang artinya tuntas. Untuk mengukur peningkatan hasi belajar peserta didik peneliti menggunakan hasil dari pre test dan post test yang diberikan. Apabila dilihat dari segi perbandingan rata-rata hasil belajar pada ranah kognitif secara individu terlihat bahwa nilai ratarata post test > pre test pada pertemuan pertama dengan selisih $39,43 \%$, kemudian pada pertemuan kedua selisihnya yaitu sebesar $29,7 \%$ dan untuk pertemuan ketiga dengan selisih $23,09 \%$, dengan peningkatan nilai $\mathrm{N}$-Gain untuk pertemuan pertama yaitu sebesar 0,66 dengan kategori sedang, pada pertemuan kedua peningkatan N-Gain yaitu sebesar 0,59 dengan kategori sedang, dan untuk pertemuan ketiga peningkatan N-Gain yaitu sebesar 0,51 dengan kategori sedang. Kemudian perbandingan rata-rata hasil belajar kognitif secara kelompok terlihat bahwa nilai rata-rata post test $>$ pre test pada pertemuan pertama selisisnya yaitu sebesar $30,36 \%$, Kemudian pada pertemuan kedua selisihnya yaitu sebesar $29,37 \%$, dan pada pertemuan ketiga selisihnya yaitu sebesar $20,7 \%$. dengan peningkatan nilai $\mathrm{N}$-Gain untuk pertemuan pertama yaitu sebesar 0,7 dengan kategori tinggi, pada pertemuan kedua peningkatan $\mathrm{N}$ Gain yaitu sebesar 0,66 dengan kategori sedang, dan untuk pertemuan ketiga peningkatan N-Gain yaitu sebesar 0,61 dengan kategori sedang sesuai dengan indikator $\mathrm{N}$ Gain Hake. Hal ini menunjukan bahwa peserta didik sebelum dan sesudah memiliki pengetahuan awal yang diperoleh dari pembelajaran pada tingkat sebelumnya maupun dari lingkungan sekitar dan lebih memahaminya setelah diterapkan model pembelajaran Team Based Learning dalam proses pembelajaran.

Berdasarkan uraian diatas, dapat disimpulkan bahwa perangkat pembelajaran memenuhi kriteria efektif untuk digunakan dalam proses pembelajaran Fisika di SMA.

\section{SIMPULAN DAN SARAN}

Berdasarkan hasil penelitian yang telah dilakukan, dapat disimpulkan bahwa, kualitas pengembangan perangkat pembelajaran dengan menggunakan model Team Based Learning pada materi keseimbangan dan dinamika rotasi yang telah dikembangkan masuk dalam kategori valid dengan skor ratarata 3,0-3,4 (baik), dan layak untuk diuji coba. Tingkat keefektifan terlihat dari persentase ratarata penilaian hasil belajar (kognitif, afektif dan psikomotorik) berada dalam kategori baik. Serta tingkat kepraktisan dengan melihat persentase rata-rata keterlaksanaan pembelajaran yang dilakukan oleh guru sebesar $95 \%$ dalam kategori sangat baik. Berdasaran kesimpulan maka peneliti menyarankan guru dapat melakukan pengembangan yang dimilikinya sesuai dengan karakteristik materi dan kebutuhan peserta didik, perlu adanya pengembangan perangkat pembelajaran yang menggunakan model yang mengarahkan siswa untuk belajar secara mandiri dan mengaitkan materi pembelajaran dengan kondisi lingungan peserta didik agar lebih mudah memahami materi yang diajarkan, dan perlu adanya penelitian lebih lanjut dalam skala lebih luas tentang pengembangan perangkat pembelajaran khususnya dalam proses pembelajran daring.

\section{UCAPAN TERIMAKASIH}

Ucapan terimakasih kami sampaikan kepada pihak sekolah SMAN 4 Gorontalo selaku mitra peneliti dalam pelaksanaan penelitian.

\section{DAFTAR RUJUKAN}

Direktur Jenderal Pendidikan Tinggi Republik Indonesia. (2020). Surat Edaran Direktur Jenderal Pendidikan Tinggi Republik Indonesia Nomor 1 Tahun 2020 tentang Pencegahan Penyebaran Corona Virus Disease (Covid-19) di Perguruan Tinggi, Kementerian Pendidikan dan Kebudayaan.

Handarini, O. I., \& Wulandari, S. S. (2020). Pembelajaran Daring Sebagai Upaya Study Form Home (SFH) Selama Pandemi Covid 19. Jurnal Pendidikan Administrasi Perkantoran (JPAP), 8(3), 496-503. Retrieved from https://journal.unesa.ac.id/index.php/jp ap/article/view/8503

Islamarida, R. (2019). Team Based Learning (TBL) Dalam Peningkatan Pengetahuan, Hasil Belajar Dan Kerjasama: Literature Review. Jurnal EDUNursing, 3(1), 12-18. Retrieved 
from

http://journal.unipdu.ac.id:8080/index.p $\mathrm{hp} /$ edunursing/article/view/1830

Lohman, M. C., \& Finkelstein, M. (2002). Designing cases in problem-based learning to foster problem-solving skill. European Journal Of Dental Education, 6(3), 121-127. Retrieved from https://pubmed.ncbi.nlm.nih.gov/12269 $\underline{867 /}$

Michaelsen, L. K., Davidson, N., \& Major, C. H. (2014). Team-Based Learning Practices and Principles in Comparison with Cooperative Learning and Problem-Based Learning. Journal on Excellence in College Teaching, 25(34), 57-84. Retrieved from http://celt.miamioh.edu/ject/issue.php? $v=25 \& n=3$ and 4

Michaelsen, L. K., \& Sweet, M. (2008). The essential elements of team-based learning. New Directions for Teaching and Learning, (116), 7-27. https://doi.org/10.1002/tl.330

Mustaming, A., Mochamad, C., \& Luthfiyah, N. (2015). Pengembangan Perangkat Pembelajaran Meperbaiki Unit Kopling dan Komponen-Komponen Sistem Pengoperasiannya Dengan Model Discovery Learning untuk Meningkatkan Hasil Belajar Siswa Kelas XI Otomotof SMK Negeri 2 Tarakan. Pendidikan Vokasi: Teori Dan Praktik, 3(1), 81-95. Retrieved from https://ejournal.unesa.ac.id/index.php/ pendidikan-vokasi-teori-danprak/article/view/13565

Persky, A. M. (2012). The impact of team-based learning on a foundational pharmacokinetics course. American Journal of Pharmaceutical Education, 76(2), $1-10$. https://doi.org/10.5688/ajpe76231

Purwanto, A., Pramono, R., Asbari, M., Hyun, C., Wijayanti, L., Putri, R., \& santoso, priyono. (2020). Studi Eksploratif Dampak Pandemi COVID-19 Terhadap Proses Pembelajaran Online di Sekolah Dasar. EduPsyCouns: Journal of Education, Psychology and Counseling, 2(1), 1-12. Retrieved from https://ummaspul.ejournal.id/Edupsycouns/article/view/39 7

Trianto. (2008). Mendesain Pembelajaran Kontekstual (Contekxtual Teaching And Learning) di Kelas. Jakarta: Cerdas Pustaka Publisher. 